\title{
Specificity of a Particulate Glucosyltransferase in Seedlings of Pisum sativum L. Which Catalyzes the Formation of $5^{\prime}-O-(\beta-D-$ Glucopyranosyl)Pyridoxine ${ }^{1}$
}

\author{
Kenjiro TADERA, Fumio YAGI, and Akira KOBAYASHI ${ }^{2}$ \\ Laboratory of Biochemistry and Nutritional Chemistry, \\ Department of Agricultural Chemistry, Faculty of Agriculture, \\ Kagoshima University, Korimoto, Kagoshima 890, Japan
}

(Received December 21, 1981)

\begin{abstract}
Summary A glucosyltransferase, catalyzing the transfer of D-glucose from UDP-glucose to the 5'-hydroxyl group of pyridoxine, was isolated as a particulate enzyme from seedlings of podded pea (Pisum sativum L. cv. Kinusaya). The enzyme required additional $\mathrm{Mg}^{2+}$ for its function. The $\mathrm{pH}$ optimum for glucosylation of pyridoxine was between 7.8 and 8.8. The enzyme showed high specificity for UDP-glucose and relative specificity for glucosyl acceptor: pyridoxine was replaceable by pyridoxamine. Several compounds tested other than vitamin $B_{6}$ failed to serve as the acceptor. It was shown that a methylene group on C-4 participated in the formation of enzyme-substrate complex, and that the rate of glucosylation was dependent upon the C-4 substituent. From the results of kinetic studies and an experiment in vivo, the enzyme was inferred to be UDPglucose: pyridoxine $5^{\prime}-O-\beta$-glucosyltransferase.
\end{abstract}

Key Words pyridoxine 5'- $\beta$-glucoside, glucosyltransferase, glucosylation, HPLC of vitamin $B_{6}$

Vitamin $\mathrm{B}_{6}$ in higher plants is known to occur in bound forms of pyridoxine (PN) $(1-5)$. The dominant bound form in cereals and seeds of vegetables is $5^{\prime}-O-(\beta-$ D-glucopyranosyl)pyridoxine (PN-Glc) $(6,7)$, and is accepted to be formed from PN in some seedlings $(8,9)$. Our previous communication reported the occurrence of a particulate enzyme in seedlings of podded pea (Pisum sativum L. cv. Kinusaya), which catalyzed the transfer of D-glucose from UDP-glucose to the $5^{\prime}$-, but not 4'-, hydroxyl group of PN (9). The present paper describes the substrate specificity and some properties of this glucosyltransferase, which is deduced to be UDP-glucose: pyridoxine $5^{\prime}-O$ - $\beta$-glucosyltransferase.

${ }^{1}$ Presented in part at the Annual Meeting of the Agricultural Chemical Society of Japan, Fukuoka, Japan, April 1980.

${ }^{2}$ 田寺謙次郎, 八木史郎, 小林 昭 


\section{MATERIALS AND METHODS}

Materials. ADP-glucose, UDP-glucose, GDP-glucose, UDP-galactose, glucose-1-phosphate, methyl- $\beta$-glucoside and $\beta$-glucosidase were purchased from Sigma Co., quercetin from Tokyo Kasei Co., thiamin hydrochloride from Daiichi Pure Chemicals Co., glucomesser reagent from Shinotesto Co., Shodex HC-125S resin from Showa Denko Co., and other reagents from Nakarai Co. Seeds of Pisum sativum L. cv. Kinusaya and others were obtained from commercial sources.

$o$-Nitrophenyl- $\beta$-glucoside was synthesized according to the method of Glaser and Wulwek (10). $N$-Methylpyridoxine $(N$-MePN) was prepared by the method of Ichiba et.al.(11). A pure specimen of PN-Glc was prepared from germinated rice seeds grown on a PN solution (8). Glucosides of 4'-deoxypyridoxine (DOP) and pyridoxamine $(\mathrm{PM})$ were isolated from reaction mixtures according to the method for PN-Glc (9). Their chemical structures were confirmed as follows: hydrolysis of the glucosides with $\beta$-glucosidase (8) gave equimolecular amounts of glucose and each aglycone, glucose being determined with glucomesser reagent and aglycones by measurements of absorbancy; the glucosides were positive to 2,6-dichloroquinone chlorimide, indicating that glucose was bound to the 5'-hydroxyl group of each aglycone (12).Spectrophotometry showed that glucosides of DOP and PM were almost pure.

Determination of protein. Protein was determined using a modified Lowry method with bovine serum albumin as the standard (13).

Preparation of particulate enzyme. Seeds of podded pea, Pisum sativum L. cv. Kinusaya, were germinated and cultivated on cotton layers moistened with water at $25-30^{\circ} \mathrm{C}$ for 5 days in the dark. Distilled water was added daily. Seedlings, weighing $20 \mathrm{~g}$, were homogenized in a chilled mortar with sea sand and $60 \mathrm{ml}$ of $0.1 \mathrm{M}$ sodium phosphate buffer ( $\mathrm{pH} 7.5$ ) containing $0.4 \mathrm{M}$ mannitol, $2 \mathrm{~mm}$ ethylenediaminetetraacetate (EDTA) and $1 \mathrm{~mm}$ 2-mercaptoethanol. The homogenate was squeezed through gauze and the filtrate was centrifuged at $20,000 \times g$ for $15 \mathrm{~min}$ at $2^{\circ} \mathrm{C}$. The supernatant solution was then centrifuged at $50,000 \times g$ for $45 \mathrm{~min}$. The pellet was suspended, using a Potter-Elvehjem teflon homogenizer, with $30 \mathrm{ml}$ of the same buffer solution omitting mannitol. The suspension was centrifuged again at $50,000 \times g$, and the pellet was suspended in an appropriate volume of $0.1 \mathrm{M}$ sodium phosphate buffer $(\mathrm{pH} 7.8)$ to give a protein concentration of $3.0 \mathrm{mg} / \mathrm{ml}$ unless otherwise mentioned.

Assay of enzyme activity. Basal conditions of the assay of enzyme activity were as follows: $1 \mathrm{ml}$ reaction mixture composed of $1 \mu \mathrm{mol}$ of acceptor, $2 \mu \mathrm{mol}$ of donor, $3 \mu \mathrm{mol}$ of $\mathrm{MgCl}_{2}, 0.6 \mathrm{mg}$ of the enzyme preparation and $100 \mu \mathrm{mol}$ of sodium phosphate ( $\mathrm{pH} 7.8$ ) was incubated at $30^{\circ} \mathrm{C}$ for $30 \mathrm{~min}$ in the dark. The reaction was stopped by immersing the incubation tube in a boiling water bath for $5 \mathrm{~min}$, and the cloudy precipitate was removed by centrifugation. The products in the supernatant were analyzed in the following way.

Determination of glucosides of $P N, D O P$ and $P M$ by high-performance liquid 
chromatography. The instrument used was a high-performance micro liquid chromatograph system of Japan Spectroscopic Co., the Familic-100, connected with a Uvidec-100-II as a UV flow analyzer. A teflon column of $0.5 \times 400 \mathrm{~mm}$ was packed with Shodex HC-125S resin. An aliquot of the reaction mixture $(2-4 \mu \mathrm{l})$ was applied to the column. The glucoside of PN, DOP or PM was eluted from the column by running three solvent systems respectively, i.e. $0.3 \mathrm{M}$ sodium phosphate buffer of $\mathrm{pH}$ $7.15,7.80$ or dibasic sodium phosphate at a rate of $8 \mu \mathrm{l} / \mathrm{min}$ at room temperature. Absorption of the effluent was recorded at $320 \mathrm{~nm}$. Each glucoside was eluted faster than its aglycone, and resolution of the two peaks was satisfactory for quantitation. The peak area on a chromatogram was integrated by the HW method of Spackman et al.(14), and the amount of glucoside was calculated from the peak area compared with that of the specimen. This analytical system allowed a precise quantitation of more than $0.01 \mathrm{nmol}$ of the products.

Detection of glucosides other than $P N-, D O P$ - and PM-glucosides. The reaction mixture, $50 \mu \mathrm{l}$, was streaked on a $2 \times 40 \mathrm{~cm}$ sheet of Toyo No. 51 chromatography paper, and developed with $n$-butanol/pyridine/water $(6: 4: 3, \mathrm{v} / \mathrm{v} / \mathrm{v})$ or $n$-butanol/ acetic acid/water $(4: 1: 2)$. The fluorescent products of enzyme action on PN, DOP, PM, 4-pyridoxic acid (PIC), PN-Glc, thiamin, riboflavin and quercetin were sought on paper under an ultraviolet lamp. In the case of thiamin, the chromatogram was sprayed in advance with the potassium ferricyanide reagent (15). The silver nitratesodium hydroxide reagent was employed as a color-producing reagent for examining the reaction product(s) from glucose.

The glucoside of pyridoxal (PL), $N$-MePN or $o$-nitrophenol was detected by high-performance liquid chromatography using the eluting solvent of $0.3 \mathrm{M}$ sodium phosphate buffer of $\mathrm{pH} 6.95,7.15$ or tribasic sodium phosphate, respectively.

RESULTS

\section{Some properties of the enzyme}

The rate of glucosylation was linear with incubation time for at least $50 \mathrm{~min}$ and proportional to protein concentration up to $2.5 \mathrm{mg}$ per $\mathrm{ml}$ of the reaction mixture.

The enzyme required additional $\mathrm{Mg}^{2+}$ for its function, and the apparent $K_{\mathrm{m}}$ value was estimated from the Lineweaver-Burk plot to be $1.0 \mathrm{mM} . \mathrm{Mg}^{2+}$ was partially replaceable by $\mathrm{Mn}^{2+}$ (the relative activity of $40 \%$ ), but not by $\mathrm{Fe}^{2+}$ or $\mathrm{Zn}^{2+}$.

The $\mathrm{pH}$ optimum for glucosylation of $\mathrm{PN}$, determined in three different buffer systems, was between 7.8 and 8.8 (Fig. 1).

Table 1 shows the substrate specificity of the enzyme for glucosyl donor. The enzyme activity was found only with UDP-glucose, but not with methyl- $\beta$ glucoside, $o$-nitrophenyl- $\beta$-glucoside, cellobiose or glucose-1-phosphate, indicating that the enzyme belonged to glucosyltransferase but not to $\beta$-glucosidase or phosphorylase. Sugar nucleotides such as GDP-glucose, ADP-glucose and UDP- 


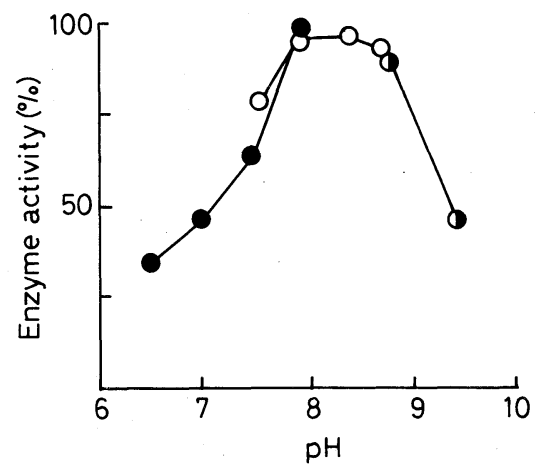

Fig. 1. Effect of $\mathrm{pH}$ on the glucosyltransferase activity. PN and UDP-glucose were incubated with enzyme under the conditions given in MATERIALS AND METHODS by the use of $0.1 \mathrm{M}$ buffers of phosphate $(\bullet)$, Tris- $\mathrm{HCl}(\mathrm{O})$ and glycine- $\mathrm{NaOH}(\boldsymbol{\bullet})$.

Table 1. Substrate specificity of glucosyltransferase for glucosyl donor.

Assays were conducted under the standard conditions except for the substituted glucosyl donors.

\begin{tabular}{lc}
\hline \multicolumn{1}{c}{ Donor } & $\begin{array}{c}\text { Relative rate of glucosylation } \\
\text { (UDP-glucose =100) }\end{array}$ \\
\hline UDP-glucose & 100 \\
UDP-galactose & 0 \\
ADP-glucose & 0 \\
GDP-glucose & 0 \\
$o$-Nitrophenyl- $\beta$-D-glucoside & 0 \\
Glucose-1-phosphate & 0 \\
Methyl- $\beta$-D-glucoside & 0 \\
Cellobiose & 0 \\
Glucose & 0 \\
\hline
\end{tabular}

galactose failed to serve as the glucosyl acceptor. The enzyme showed high specificity for both the nucleotide- and sugar-moieties of sugar nucleotide.

Table 2 shows the substrate specificity of the glucosyltransferase for other glucosyl acceptors. High activity was observed with PN and DOP, and weak activity with PM. Little activity was found with PL and $N$-MePN. No glucoside was formed from the several compounds tested, with the exception of vitamin $\mathrm{B}_{6}$. PN-Glc did not show any cleavage during the incubation, showing that $\beta$-glucosidase, even if present, did not act on PN-Glc under these conditions.

Kinetics

The open circles in Figs. 2 and 3 show a relationship between the rate of glucosylation and the substrate concentration in the Lineweaver-Burk plot. The 
Table 2. Substrate specificity of glucosyltransferase for glucosyl acceptor.

Assays were conducted under the standard conditions except for the amount of enzyme protein used, $2 \mathrm{mg}$, and except for the use of glucosyl acceptors instead of PN.

\begin{tabular}{lc}
\hline Acceptor & $\begin{array}{c}\text { Relative rate of glucosylation } \\
(\mathrm{PN}=100)\end{array}$ \\
\hline PN & 100 \\
PL & \pm \\
PM & 23 \\
PIC & 0 \\
DOP & 77 \\
$N$-MePN & \pm \\
PN-Glc & 0 \\
$o$-Nitrophenol & 0 \\
Riboflavin & 0 \\
Thiamin & 0 \\
Quercetin & 0 \\
Glucose & 0 \\
\hline
\end{tabular}

${ }^{a}$ Incubation was carried out for $2 \mathrm{hr}$.
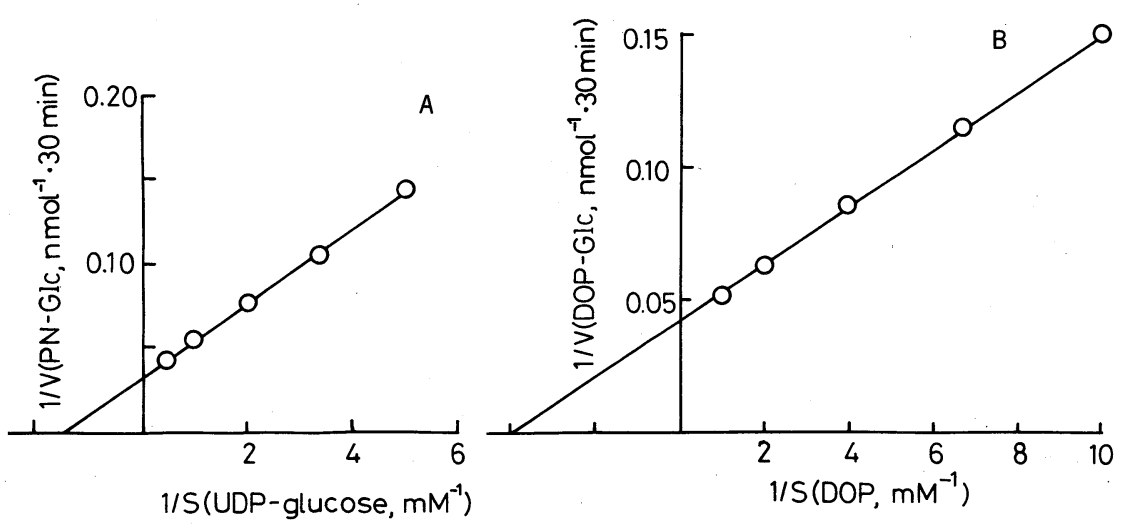

Fig. 2. Double reciprocal plot of reaction rate against substrate concentration. The assay conditions were as described under MATERIALS AND METHODS with the exception of the varying concentrations of UDP-glucose (A) or DOP (B) as shown.

apparent $K_{\mathrm{m}}$ and $V_{\max }$ values for PN, PM and DOP, obtained at the UDP-glucose concentration of $2 \mathrm{mM}$, were as listed in Table 3 . Although the values of $K_{\mathrm{m}}$ were similar among the three substrates, those of $V_{\max }$ differed appreciably. When $1 \mathrm{~mm}$ PN was the glucosyl acceptor, the $K_{\mathrm{m}}$ value calculated for UDP-glucose was $0.67 \mathrm{~mm}$ and the $V_{\max }$ value, $31.4 \mathrm{nmol} / 30 \mathrm{~min}$.

\section{Kinetic study of the inhibition of glucosyltransferase}

Figure 3 shows double reciprocal plots of the reaction rate against PN and PM Vol. 28, No. 4, 1982 

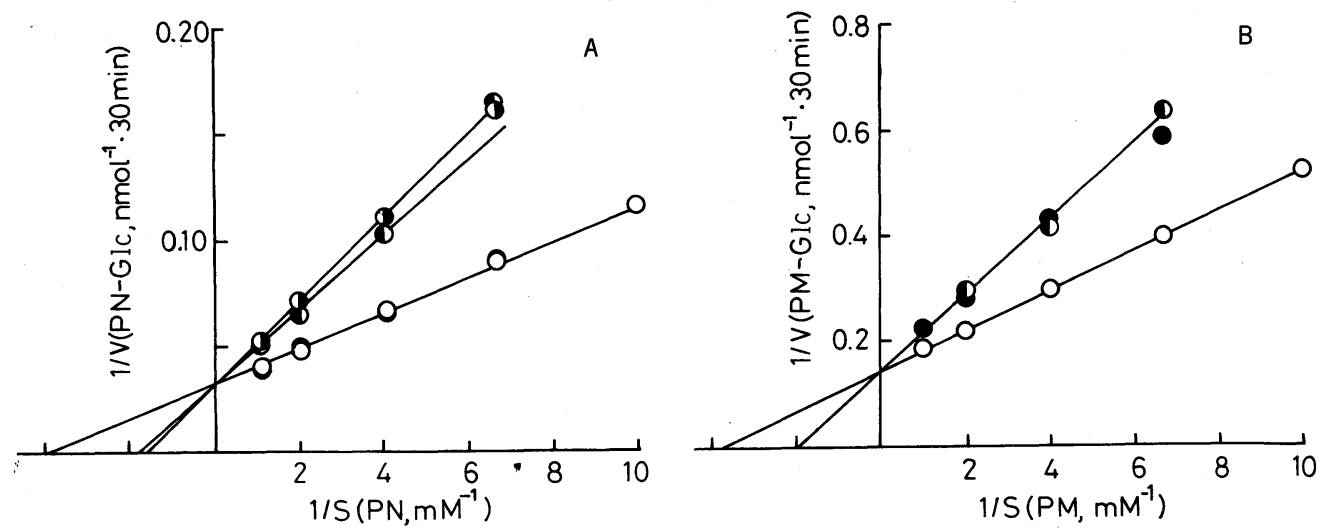

Fig. 3. Double reciprocal plot of reaction rate against substrate concentration in the presence and absence of inhibitors. The assay conditions were as described under MATERIALS AND METHODS with the exceptions that the concentrations of acceptor (PN (A); PM (B)) were varied as shown, and that the inhibitors were added at a fixed concentration of $0.3 \mathrm{mM}$. Absence of inhibitor (O). Inhibitors: (A) PM (O),

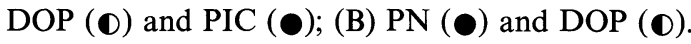

Table 3. Apparent $K_{\mathrm{m}}$ and $V_{\max }$ values for acceptors.

\begin{tabular}{cccc}
\hline Acceptor & $\begin{array}{c}K_{\mathrm{m}} \\
(\mathrm{mM})\end{array}$ & $\begin{array}{c}V_{\max } \\
(\mathrm{nmol} / 30 \mathrm{~min})\end{array}$ & $V_{\text {max }} / K_{\mathrm{m}}$ \\
\hline PN & 0.25 & 30.4 & 122 \\
PM & 0.26 & 6.8 & 26 \\
DOP & 0.25 & 23.4 & 94 \\
\hline
\end{tabular}

The values were obtained with $2 \mathrm{~mm}$ UDP-glucose.

Table 4. Affinities of competitive inhibitors for the enzyme.

\begin{tabular}{clc}
\hline Acceptor & $\begin{array}{c}\text { Inhibitor } \\
(0.3 \mathrm{mM})\end{array}$ & $\begin{array}{c}K_{\mathrm{i}} \\
(\mathrm{mM})\end{array}$ \\
\hline PN & PM & 0.24 \\
& DOP & 0.26 \\
PM & PIC & no inhibition \\
& PN & 0.26 \\
& DOP & 0.26 \\
\hline
\end{tabular}

substrate concentration in the absence or presence of $0.3 \mathrm{~mm}$ inhibitors (Fig. 3A, PN as substrate; $3 \mathrm{~B}, \mathrm{PM})$. PM was a competitive inhibitor of glucosylation of $\mathrm{PN}$, and vice versa. DOP competed with both PN and PM. PIC did not inhibit glucosylation of PN. Inhibitor constants calculated from Fig. 3 are listed in Table 4. 


\section{Biosynthesis of glucosides of $P N$ and PM in plant seedlings}

Biosynthesis of PN-Glc from PN was examined in various plant seedlings as described in the previous paper $(8,9)$. Seedlings applied were of soybean, cow pea, jack bean, Japanese radish, Chinese cabbage, spinach, rice and corn. PN-Glc was formed from PN in all the tested seedlings, but pyridoxine-4'-glucoside little formed. On the other hand, the formation of PM-glucoside, examined similarly in seedlings of podded pea, was scarcely detected.

\section{DISCUSSION}

It can be deduced from the following evidence that glucosylations of PN and PM are catalyzed by an identical enzyme but not by two respective ones. 1) A crosscompetition between PN and PM was present (Fig. 3). 2) Inhibitor constant for PN, obtained with PM as the substrate, showed a similar value to the apparent Michaelis constant for PN (Tables 3 and 4). The same held also for PM. 3) DOP competitively inhibited glucosylations of $\mathrm{PN}$ and $\mathrm{PM}$, and gave the same $K_{\mathrm{i}}$ value on exposure of either substrate thereto (Table 4).

The two $K_{\mathrm{i}}$ values for DOP, obtained with PN and PM as the substrates, were identical to its apparent $K_{\mathrm{m}}$ value (Tables 3 and 4). DOP also must be, accordingly, glucosylated by the same enzyme.

High specificity of the enzyme for UDP-glucose as the donor indicated its designation as UDP-glucosyltransferase (Table 1).

As for the acceptor, the glucosyltransferase showed relative specificity. Among the tested compounds PM replaced PN, though the enzyme activity was low. DOP, having a methyl group on $\mathrm{C}-4$, also was a good acceptor. These three compounds have in common the methylene group on C-4. Substitution of $-\mathrm{CH}_{2} \mathrm{R}$ on $\mathrm{C}-4$ for $-\mathrm{CHO}$ or $-\mathrm{COOH}$, and methylation of the ring- $\mathrm{N}$ atom brought little activity of the enzyme (Table 2), showing that the enzyme activity was dependent at least upon the $\mathrm{C}-4$ substituent and the unsubstituted ring- $\mathrm{N}$ atom. PIC failed not only to serve as an acceptor but also to inhibit the glucosylation of PN. The result reveals that the methylene group on C-4 participates in the formation of the enzyme-substrate complex.

The effects of substituents on C- 4 were examined by comparing the apparent $K_{\mathrm{m}}$ and $V_{\max }$ values for PN with those for PM and DOP. Replacement of $-\mathrm{CH}_{2}-\mathrm{OH}$ on $\mathrm{C}-4$ by $-\mathrm{CH}_{2}-\mathrm{NH}_{3}{ }^{+}$or $-\mathrm{CH}_{2}-\mathrm{H}$ did not affect affinity for the enzyme but reduced the maximum velocity of glucosylation. A marked decrease in the apparent $V_{\max }$ value was observed with PM. The ratio of $V_{\max }$ to $K_{\mathrm{m}}$ shows that $\mathrm{PN}$ is the best substrate.

PM was scarcely metabolized to PM-glucoside in seedlings of podded pea. Therefore, the glucosyltransferase seems not to act on PM in vivo, although PM can serve as acceptor in vitro for its specific structure.

From the experimental results described above, the enzyme was inferred to be UDP-glucose: pyridoxine 5'-O- $\beta$-glucosyltransferase.

Vol. 28, No. 4, 1982 
The formation of PN-Glc from PN in all the tested plant seedlings suggests the wide occurrence of the enzyme in plants.

\section{REFERENCES}

1) Siegel, L., Melnick, D., and Oser, B. L. (1943): Bound pyridoxine in biological materials. J. Biol. Chem., 149, 361-367.

2) Rabinowitz, J. C., and Snell, E. E. (1948): The vitamin B 6 group. XIV. Distribution of pyridoxal, pyridoxamine and pyridoxine in some natural products. J. Biol. Chem., 176, 1157-1167.

3) Polansky, M. M., Murphey, E. W., and Toepfer, E. W. (1964): Components of vitamin $\mathrm{B}_{6}$ in grains and cereal products. J. Assoc. Offic. Agric. Chemists, 47, 750-753.

4) Yasumoto, K., Iwami, K., Tsuji, H., Okada, J., and Mitsuda, H. (1976): Bound forms of vitamin $\mathbf{B}_{6}$ in cereals and seeds. Vitamins (in Japanese), 50, 327-333.

5) Nelson, E. W., Burgin, C. W., and Cerda, J. J. (1977): Characterization of food binding of vitamin $\mathrm{B}_{6}$ in orange juice. J. Nutr., 107, 2128-2134.

6) Yasumoto, K., Tsuji, H., Iwami, K., and Mitsuda, H. (1977): Isolation from rice bran of a bound form of vitamin $\mathrm{B}_{6}$ and its identification as 5'-O-( $\beta$-D-glucopyranosyl)pyridoxine. Agric. Biol. Chem., 41, 1061-1067.

7) Yasumoto, K., Iwami, K., Okada, J., and Mitsuda, H. (1979): A major bound form of vitamin $B_{6}$ in rice bran, wheat germ and trefoil seed and availability of its vitamin constituent for animal nutrition. Eiyo To Shokuryo (J. Jpn. Soc. Food Nutr.) (in Japanese), 32, 105-110.

8) Tadera, K., Nakamura, M., and Kobayashi, A. (1978): Biosynthesis of 5'-O-( $\beta$-Dglucopyranosyl)pyridoxine in germinated rice seeds. Vitamins (in Japanese), 52, 17-23.

9) Tadera, K., Nakamura, M., Yagi, F., and Kobayashi, A. (1979): A particulate glucosyltransferase catalyzing the formation of $5^{\prime}-O$ - $(\beta$-D-glucopyranosyl)pyridoxine from pyridoxine: the occurrence in the seedlings of Pisum sativum L. J. Nutr. Sci. Vitaminol., 25, 347-350.

10) Glaser, E., and Wulwek, W. (1924): Über neue synthetisch dargestellte Nitrophenolglucoside nebst Beiträgen zur Desinfektionskraft und Giftigkeit der Nitrophenol. Biochem. Z., 145, 514-534.

11) Ichiba, A., and Michi, K. (1938): On the chemistry of vitamin $B_{6}$. Sc. Pap. I. P. C. R., $35,73$.

12) Scudi, J. V., Bastedo, W. A., and Webb, T. J. (1940): The formation of vitamin $B_{6}$ borate complex. J. Biol. Chem., 136, 399-406.

13) Hartree, E. F. (1972): Determination of protein. Anal. Biochem., 48, 422-427.

14) Spackman, D. H., Stein, W. H., and Moore, S. (1958): Automatic recording apparatus for use in the chromatography of amino acids. Anal. Chem., 30, 1190-1206.

15) Rossi-Fanelli, A., Siliprandi, N., and Fasella, P. (1952): On the presence of the triphosphothiamine in the liver. Science, 116, 711-713. 